\title{
Catastrophic 2018 Global Climate Lessons and the Perils of Lack of Prognostic and Synoptic Data
}

\author{
Clifford Tafangenyasha* and Patmore Ngorima \\ Department of Geography and Environmental Science, University of Zimbabwe, Africa
}

Submission: February 15, 2019; Published: March 21, 2019

Corresponding author: Clifford Tafangenyasha, Department of Geography and Environmental Science, University of Zimbabwe, Zimparks, PO Box CY 140, Causeway, Harare, Zimbabwe, Africa

\begin{abstract}
The global climate scenes of 2018 were characterised by two major dominant devastating Tropical Cyclones; Cyclone Florence and Cyclone Michael that left major shocks in the weather phenomena, patterns and lessons for semi-arid Savana countries such as Zimbabwe. Lack of climate data on extent, timing, intensity, return intervals and direction of storm surges severely exposed nations to unprecedented catastrophic weather. During 2018 unusual catastrophic dry weather and winds fuelled firestorms, winds and biomass burnt out of control and ravaged very large tracts of land leaving trails of damage and human fatalities. What if weather condition prognosis was substantially improved, would environmental calamities be contained and be reduced? A large array of integrated instruments provide data relevant to weather forecasting. Increasingly Indigenous Knowledge Systems (IKS) proffer memory ecosystem changes to complement meteorological data. From sustained climate data monitoring a picture emerges of the direction of environmental conditions and ecosystems changes. From memory extreme weather events, game water supplies, wildlife and livestock populations, best performing animal breeds and best performing seed crop varieties and maximization of pheno-calendar information may be catalogued for IKS data mining. The measures reduce human fatalities, decimation of wildlife species, livestock, infrastructure damage and collapse and agricultural losses. This research emphasises the need to take the long-term view in weather tracking and climate databases in order to build adaptive capacity, particularly of the vulnerable regions on reducing exposure to episodic weather.
\end{abstract}

Keywords: Climate change; Tropical Cyclones; Trends; Patterns scenarios; Climate databases; Lessons

\section{Introduction}

Natural disasters have been recorded across the globe to include droughts, floods, and biological epidemics, extreme precipitation, extreme temperature, landslides, dry mass movements, extra-terrestrial impacts, wildfires, volcanic activity and earthquakes [1]. Ritchie \& Roser [1] compiled a relative contribution of each natural hazard into global hazard maps and noted that some nations were without entries. A hazard chart and an improve ment index of natural hazard scores provide for improvements in human wellness and safety. In Zimbabwe, a semi-arid country extreme precipitation amounts, and extreme temperatures often trigger human and environmental stress. Exhaustive environmental data may not be available to support human safety and environmental quality and as a result environmental conditions may not always be certain.

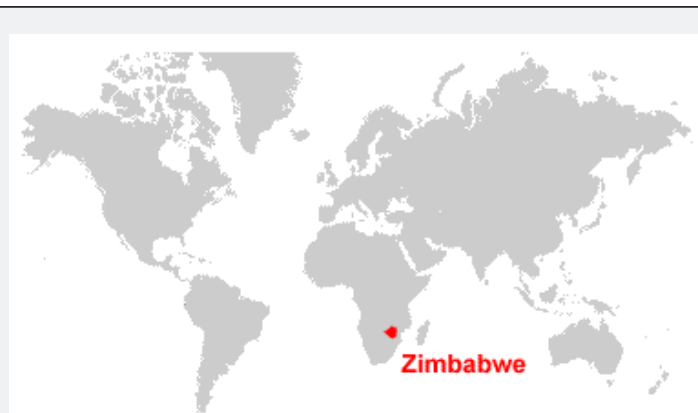

Figure 1: Situation of Zimbabwe on the global map. 
Recent climatic extremes experienced across the globe during 2018 choreographed lethal atmospheric disturbances in the form of Tropical Cyclones, storm surges, heat waves, forest fires in some parts of the globe and in others devastating droughts were recorded. In nations with advanced early warning systems, search and rescue operations coupled with environmental sensitive building codes combined to reduce human fatalities and infrastructure damage. Lethal and widespread severe atmospheric turbulences occurred in Carolina in US, the Philippines and south east China and a few other countries [2]. The resulting storm surges and floods caused human fatalities, infrastructure damage and disrupted livelihood lifestyles. Stream flow and gauge data of many African rivers (Figure 1) is lacking for many local hydrological stations to warn impending overbank floods. The change in hydrologic flood zones over a wide arc of countries in Africa may be driven by erratic precipitations but also by lack of long term and real time data.

The depravation of a much more severe nature due to environmental disturbances occur in countries with little or no record of environmental sensitivity. IPCC (2001-2004) has predicted the impending climate change that may record severe storm disturbances in others and in others extended dry weather systems that induce severe droughts. Scoones [3] has outlined some hazards and opportunities in tropical countries that include Zimbabwe and suggested need for resilience strategies to buffer climate shocks in order to improve livelihoods for the small- and large-scale farming community. The fundamental approach to climate change adaptation is hinged on the knowledge that people must be empowered with climate data to transform and secure their rights and livelihoods [4]. The need is here and now to build sensible climate databases, climate models and transact the datasets. The variability of onsets and offsets of ITCZ, Monsoon winds, El NiNo/ La NiNa and upper air circulations systems is intricately involved in formation of extreme weather leading to severe landfall patterns and severe droughts [5].

Trends, patterns and scenarios of climate are complicated by an interplay of several forcing mechanisms in the attempt to improving human safety [6-8]. The Southern Africa air movement dynamics important in precipitation or the lack of it are driven in summer largely by SW monsoon movement towards the Congo air boundary wherein the NE monsoons facilitate creation of moisture air boundary. The presence of Atlantic High and Indian Ocean High facilitate motion of Westerlies currents. In winter a strong cold air mass subsidence over Southern Africa may be caused by advancing Atlantic High and Indian Ocean High with a Westerlies cold air mass current push by the SW monsoon and SE Trade winds. Over the longer spun of time air mass movement trends in the presence of possible ENSO, El Nino and La NiNa make forecast sting capabilities essentially dependent on long term reliable data [7]. Ii is unclear to what extent climate variation is a determinant of livelihoods in Savana ecosystem functioning. It means opening the question of how really rain bearing systems over Southern Africa are connected or disconnected to regional and transcontinental energy budgets and equator dependant thermohalines.
The incidence of catastrophic droughts, forest fires, floods, heat waves, black frosts and storm surges have a negative socio-economic political impact [1]. The tropical cyclones originate over tropical or subtropical as rotating organized system of clouds and thunderstorms. A tropical disturbance arises over warm ocean waters. It can grow into a tropical depression which is an area of rotating thunderstorms with winds up to $62 \mathrm{~km}$ per hour. From them a depression evolves into a tropical storm if it its wind speed reaches $121 \mathrm{~km} / \mathrm{hr}$. When wind speed reaches $169 \mathrm{~km} / \mathrm{hr}$ a hurricane is formed. Drye [9] observed that when hurricanes hit hard, rapidly rising waters are responsible for most fatalities. Tornadoes are small-scale circulatory systems capable of devastating small areas, hurricanes are large scale. Zimbabwe is prone to tropical cyclone attacks. Landfalls and direction of cyclonic precipitation and strong winds are uncertain.

Richter \& Roser [1] noted lack of data key in averting natural catastrophes in many countries and suggested tracking weather and atmospheric circulation systems to improve environmental conditions and safety. And using appropriate measuring techniques and predictive tools to offset damage and human health calamities sustained climate condition monitoring is a growing imperative. The need is here and now to build sensible climate databases, climate models, and expansive weather parameters and to transact the datasets. The variability of onsets and offsets of ITCZ, Monsoon winds, ElNiNo/La NiNo and upper air circulations systems in concert determine type and landfall patterns, severe droughts and the quality of growing seasons $[6,10]$. As a result, a robust database based on trends, patterns and IKS should improve livelihoods and safety when episodic events strike.



Figure 2: Thermohaline circulation may be the internal forcing mechanism axis in global climate change.

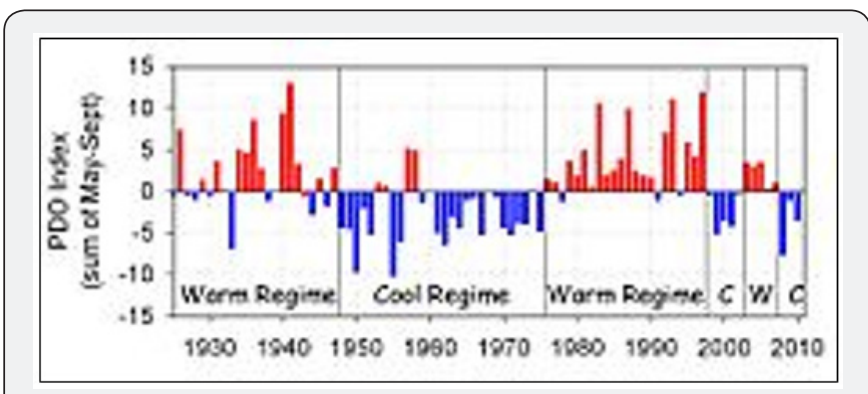

Figure 3: Pacific decadal oscillation 1925 to 2010. 
The earth's climate is affected by factors that cause a change in the redistribution of energy within the atmosphere or between the atmosphere, land and ocean. Some studies indicate that meteorological hazards can become more marked in some countries than others. This study focuses on observed data in temperature, precipitation, storms, floods, and droughts using secondary data in order to understand episodic events and their fallouts (Figures $2 \& 3$ ) display long term and trends engrossed in energy and wind dynamics in Pacific Ocean key to global climate fluxes. Windstorms, hailstorms, snowstorms, dust storms, droughts and Cyclones all have their global strike periods and periodicity [11]. Wave graphs depict amplitudes, periods, return intervals and levels of intensity of a climatic and weather phenomenon. Some effects of climate are readily apparent in eroding coastlines and unpredictable weather pattern. Other effects include changes in coral reefs and rising sea levels [12-14]. Elsewhere devastating wildfires, storms and floods have affected millions of people in the developed world over the past months. This research emphasises the need to assess and take consideration of variability in climate impacts in the adaptive management of water resources (Figure 4).

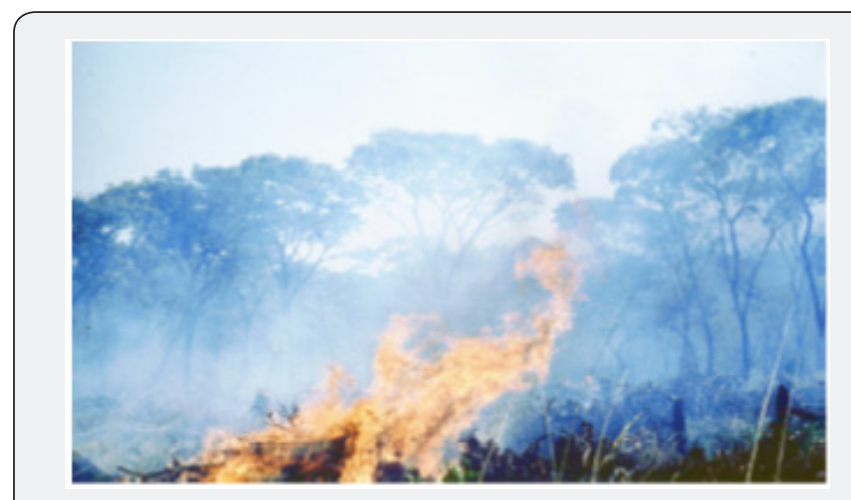

Figure 4: Slash-and-burn agriculture is widely practised in the wetter parts of the miombo region. Fire is used to burn felled trees and slash to produce a fertilising ash bed into which crops are planted - in this case, cassava - Kadoma district, Zambia.

The definitions and mechanisms for climate condition change have been elucidated by several climate monitoring practitioners [6-7,12-14]. Climate change may be a change in the statistical distribution of weather patterns when that change lasts for an extended period of time (i.e., decades to millions of years). Climate condition is defined not only by average temperature and precipitation but also by the type, frequency, duration, and intensity of weather events such as heat waves, cold spells, storms, floods, and droughts. IPCC attribute climate condition to factors such as biotic processes, variations in solar radiation received by Earth, plate tectonics, and volcanic eruptions. Certain human activities have been identified as primary causes of ongoing climate change, often referred to as global warming. Besides $\mathrm{CO} 2$, methane ( $\mathrm{CH} 4$ ), nitrous oxide (N20), fluorinated gases, ozone (03) and water vapour are important greenhouse gases [15]. Every pound of $\mathrm{CO} 2$ emitted in the last hundred years will continue to trap heat in the atmosphere for hundreds of years to come $[8,15]$.
Measurements show the concentration of carbon dioxide in the atmosphere has risen since pre-industrial times, carbon dioxide levels have $40 \%$. Fossil fuel burning and land use changes such as turning forest into agricultural have been blamed as leading causes of climate change [15]. Water vapour plays a unique role as it strengthens the heat-trapping effect caused by other greenhouse gas emissions. IPCC suggests that climate change may often lead to increased air and ocean temperatures, drought, melting ice and snow, rising sea levels, increased rainfall, flooding and other influences.

In the past in Zimbabwe, the rainy season started around the months of October and automatically, that's when the farming season began [4]. However, things have changed over the years in Zimbabwe, December is now marking the beginning of serious farming $[4,16]$. In some parts of the country, it's January. This change in farming seasons is affecting the farming activities in Zimbabwe negatively. Since the amount of rain received is now unfavourable, the effect is detrimental, and the quality of produce is now compromised, which is impacting on the quality of life of the ordinary farmers and farm workers [4] (Figure 5).

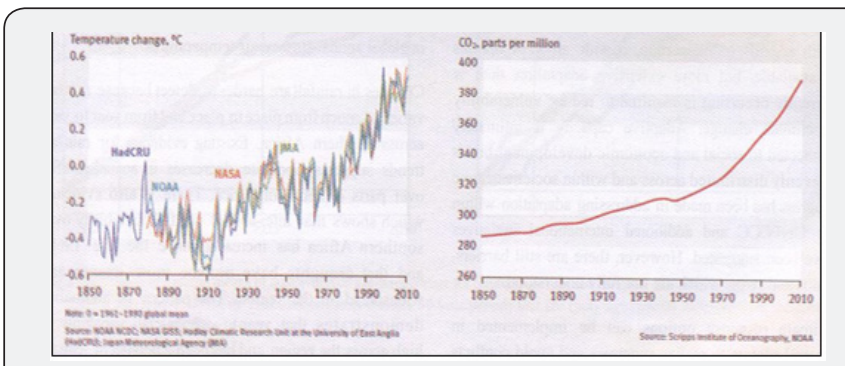

Figure 5: Trends in temperature change and atmospheric $\mathrm{CO} 2$ concentration $1850-2010$.

\section{Forcing Mechanisms of Climate Change}

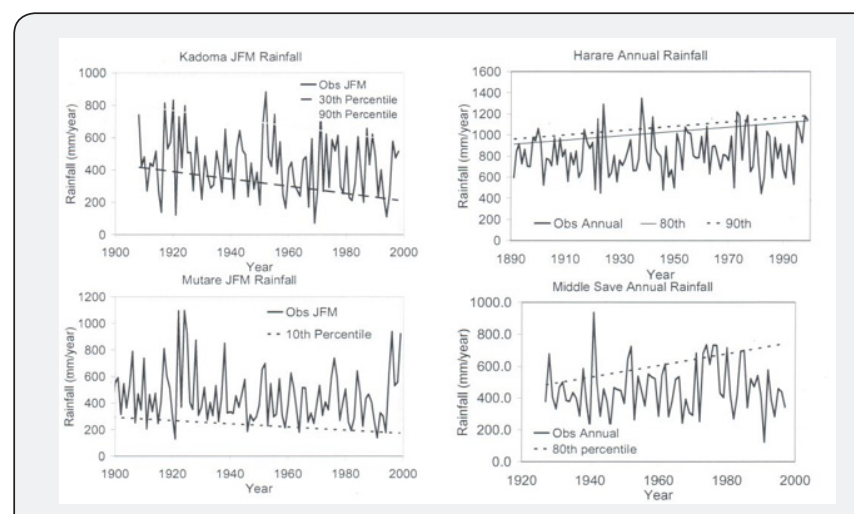

Figure 6: Long term rainfall patterns of Zimbabwe.

IPCC has made detailed prognosis of climate change. IPCC concedes that humans have been influencing the climate since the start of the Industrial Revolution in a cycle of climate external forcing mechanisms. Since then, the average world temperature has risen by approximately 0.8 degrees Celsius. The sea level has risen by around $20 \mathrm{~cm}$ and most of the glaciers have shrunk 
dramatically. Up to 1950 , the influence of nature was more important than human influence $[4,8]$. After that, the pattern in the average world temperature can only be explained by factoring in the human influence. According to the latest Intergovernmental Panel on Climate Change (IPCC), it is more than likely (more than $90 \%$ probability) that most of the global warming in recent decades is attributable to the observed increase in greenhouse gases. Observed changes in temperature, precipitation, storms, floods, and droughts have been widely reported in literature $[3,6,17,18]$ (Figure 6).

Between 1880 and 2012, earth's surface has warmed up by approximately $0.85 \mathrm{oC}$. Surface temperatures fluctuate substantially, and warming has naturally occurred more slowly in some decades than others, but (IPCC, 2007) shows a long-term warming trend. The extra heat being trapped as a result of human activities is causing glaciers and ice sheet to melt, the oceans to warm and expand its changing extreme weather events, leading to hotter hot days fewer cool nights. Under low emissions scenario sea level rise is expected to be $40 \mathrm{~cm}$, while a high emissions scenario could result in an average $63 \mathrm{~cm}$ of sea level rise. The mean temperature rise predicted under IPCC, low emissions scenario is 1 oC by 2100 , and that is a scenario where emissions must be cut aggressively [15] (Figure 7).

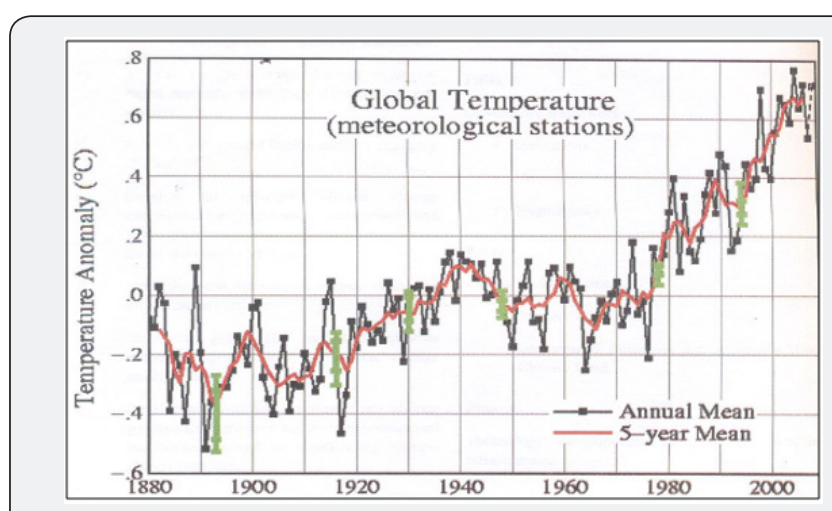

Figure 7: Global near-surface temperature from 1880-200.

Climate anomalies annihilate productive agricultural systems, infrastructure and human health [6,7]. The past decade has seen an astonishing run of record-breaking storms, forest fires, droughts, coral bleaching, heat waves, and floods around the world. Climate change impacts include stronger storms, more erratic weather, dangerous heat waves, rising seas, and large-scale disruption to infrastructure and migration patterns [19]. When global disruptive weather phenomena and patterns driven by cyclone Florence swept away wildlife, chickens, pigs and other livestock food stock losses became worrisome [9]. Large storm landfalls floods have ruptured large dams such as Tokwe-Mukosi Dam in Zimbabwe [20]. Catastrophic weather patterns invoke a new level of understanding and a new level of human ingenuity required to survive the odds. Digital elevation modelling used in conjunction with climate data precisely determine flooding zones and safety zones. Reducing global warming and deforestation is often the recipe to safety [15].

\section{Tropical Cyclone Activity}

As Saharan desert air currents roll over warm waters off the west coast of Africa, water is funnelled into a hurricane structure, circulating up and out like a chimney [21-23]. Over days or weeks, these storms build as they head west, making it more likely they will hit the Coast as a major hurricane [7]. Warmer-than-average temperatures, and warm water fuels hurricanes. Wind usually forces a hurricane to become uneven and lose strength. Florence peak winds at times exceeded $140 \mathrm{~km} / \mathrm{hr}$ [9]. Without this dry air to deter the hurricane, it can form a tighter core, which helps keep the eye intact as it moves across the masses of ocean waters. This more sustained structure means the storm could continue to rapidly intensify Wind speeds can double in less than an hour. Warm waters, low wind shear, and a tight core are the three most essential features hurricanes need to gain strength and make a big impact when they hit land. Factors that caused Florence to weaken not detected by models (Figure 8).

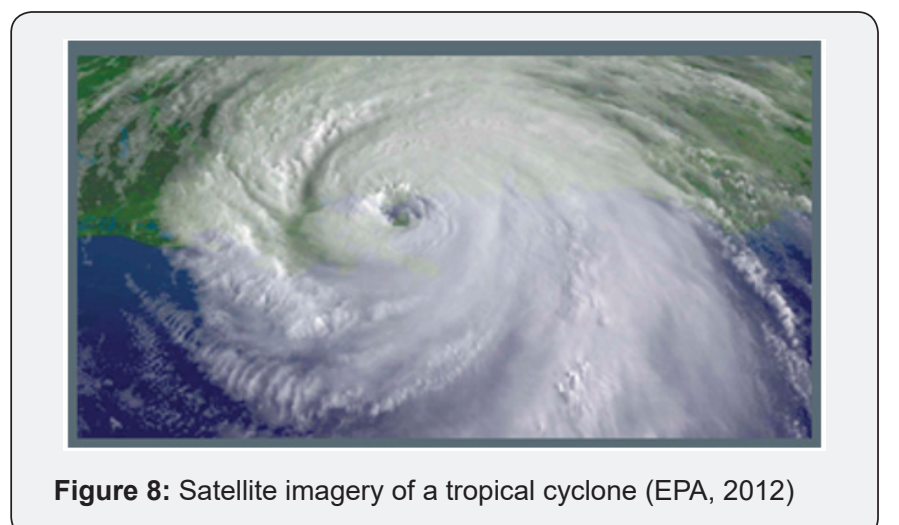

Tropical cyclones develop over the Indian Ocean in the region bounded by latitude 5-20oC South and longitudes 50-90oC East. Most of these storms usually move initially westwards towards or across Madagascar and the eastern shores of Mozambique, eventually turning southward into the westerly airstream. The remnants of Hurricane Florence were felt by residents in flood zones in drama not previously experienced. The hurricanes caused severe flooding in the Carolinas in USA. Tropical Cyclone Michael occurred a month after North and South Carolina was damaged by destructive Hurricane Florence [2], Hurricane Michael was the 13th major storm identified in the Atlantic hurricane season as it moved north through the Gulf of Mexico, to damage U.S. East Coast. Other severe hurricane storm surges and flooding caused death and chaos in the Philippines and China [24].

Increasingly, climate monitoring practitioners are linking climate change to a more dangerous hurricane season usually between August and January. Warmer temperatures can carry more moisture [25,26]. Warmer ocean waters lead to hurricanes that dump more intense-and deadly—rainfall. Holt et al. [27] invited caution in attempts to cast precision in cyclone landfalls and suggested visualising uncertainties in storm surge forecasting data. IPCC has long predicted that extreme weather events, such as cyclones, flooding and droughts will increase in frequency and 
severity over the next decades. Rainfall in Southern Africa is to a large extent governed by the ITCZ $[5,25,28]$. With the southward migration of the sun, pressure falls over the interior of the African continent, allowing the northward shift of the ITCZ [23]. The ITCZ moves between the latitudes.

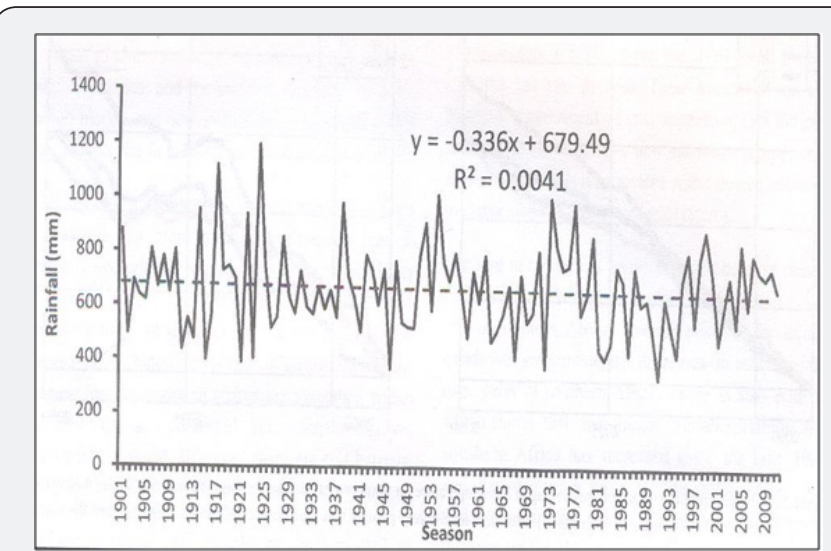

Figure 9: Time series of the national average rainfall for Zimbabwe 1901-2009 (Met-station, 2010)

Rainfall patterns are expected to change by the end of the century, wet regions getting wetted and dry regions getting drier. Winkler [15] suggest that under the high emissions scenario, some places will receive up to $50 \%$ more rainfall, while other receive up to $30 \%$ less. Forests provide essential services for the livelihood of people. The services likely affected by high emissions include household energy/fuel wood, soil conservation, water cycling and access to water, and biodiversity. (Figure 9-11) Poor people are more likely to live and work in areas exposed to potential climatic hazards, while they are less likely to have the resources to cope when a disaster strikes [4]. Secure livelihoods and higher incomes increase resilience and enable people to recover more quickly from a hazard. Improved databases and benchmarks through Indigenous Knowledge Systems (IKS) in climate monitoring strengthens early mitigations during catastrophic episodic climate [29] (Figure 12).

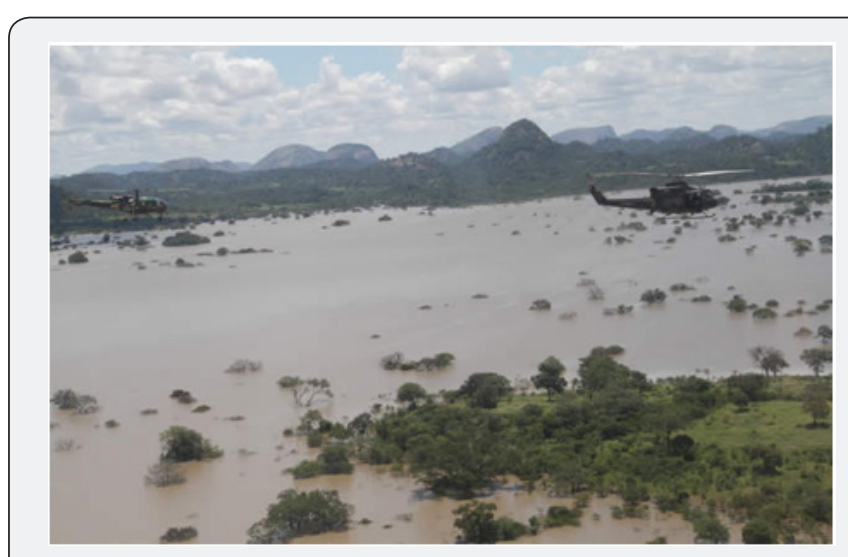

Figure 10: Search and rescue operations during storm surge of Muzarabani (Zimbabwe) flood prone areas
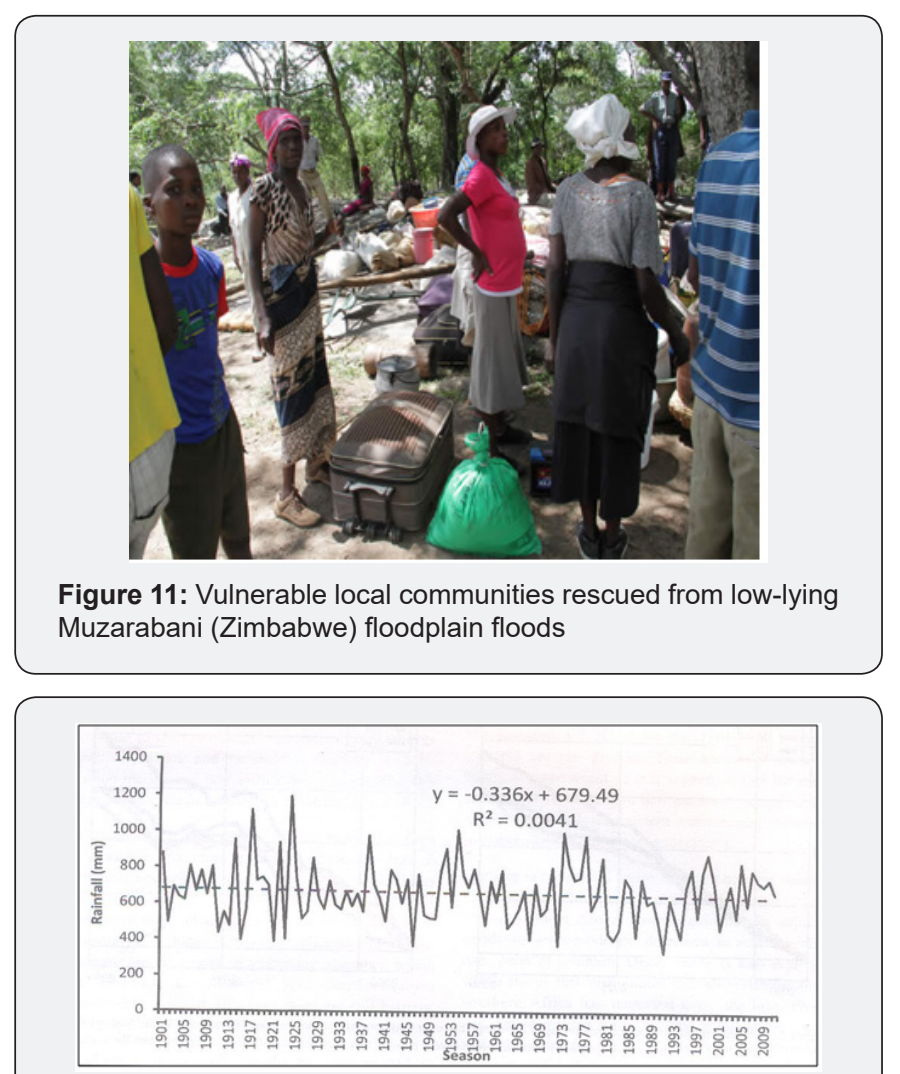

Figure 12: Time series of the national average rainfall for Zimbabwe 1990-2009.

\section{Dry Weather Development}

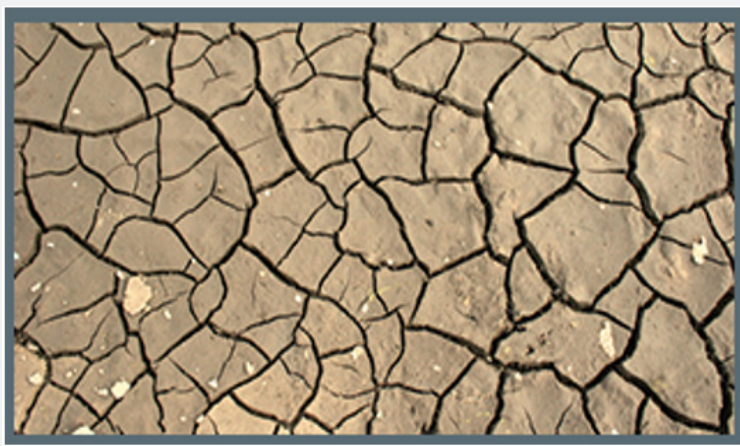

Figure 13: Year to year rainfall variability is high in Savana's with the 1970's being relatively wet while the period 1980-1990 have been relatively dry (After EPA, 2012).

The region experiences a hot wet season during NovemberMarch, a cool dry season during April-July and a hot dry season during August-October. Mean maximum temperatures exceed $30^{\circ} \mathrm{C}$ during all months except June and July. The low-lying area of Zimbabwe areas is noted for low, but very variable, annual rainfall. In the north of the Gonarezhou park, annual rainfall averaged 516 $\mathrm{mm}$ (coefficient of variation 40\%), ranging from $93 \mathrm{~mm}$ during the 1991/92 drought [30], to $1118 \mathrm{~mm}$ during 1999/2000, when cyclone Eline caused extensive flooding [31], During dry years, 
water was pumped to what would otherwise be seasonal pans. The change in planting seasons has been strong, with agro ecological seasons requiring revisions as some seasons have shifted [4]. Changes in key drivers of climate and occurrences of Tropical Cyclones, hurricanes, tornadoes, and typhoons should be appropriately calibrated in the early warning signals [32-35]. Winkler [15] proposed practical climate change mitigation in South Africa by moving towards a low carbon economy and suggested closing gaps in the paucity of climate data. Lem [36] conceded that best decisions are based on what is known with climate data and that many things remain to be known by extending the range of weather observation records in the pursuits of improvements in prognostic data and synoptic charts (Figure 13).

Drought is the single most crucial natural disaster that affects Southern Africa [37,38]. Guranyanga [34] and contend that droughts may be occurring every 10-15 years. Since the turn of the century, eight spells of more or less than nine years have alternated with similar periods of rainfall. Rainfall measured at Zimbabwe Sengwa Wildlife Station show a decreasing trend from 1965 to the 2015 period [39]. (Figure 14)



Figure 14: Long term rainfall record (Mean $=670.4 \mathrm{~mm}, \mathrm{n}=50$ years, $C V=25.6 \%$ ) at SWRA Note that missing cases are responsible for the crunch after 2007 in the figure

In a study of the impacts of a severe drought in the Gonarezhou National Park by Tafangenyasha [39], biweekly assessments of the number of leaf buds, young, mature leaves and dead leaves, flower buds, open flowers, unripe and ripe fruits showed a gradual deterioration in the food supply in a season of low rainfall. A large proportion of the woody species was killed during the 1991-92 drought. Observations of impacts of climate have been extended to flagship and keystone species Baobab (Adansonia digitata) of ecological significance in ecosystem function. Greenhouse gases, climate change, and global warming appear to be factors reducing baobab longevity. Some regions of the worlds that boundaries of woodland areas and grassland areas are likely to shift in response to shifts in climate belts [40]. Ecosystem changes are likely to affect distributions of wildlife (including fish) and to some degree derived livelihoods of local communities.

An analysis of long-term changes to precipitation suggests that no definite pattern of this phenomenon in Zimbabwe has been found yet [16]. Figure 14 shows the long-term precipitation pattern at the major meteorological stations of Zimbabwe. The extremes of severe weather patterns may result in increased frequencies of severe droughts, surface water scarcity, wildlife deaths of principal grazing species and in some other year's cyclonic precipitation result in floods. Livelihood options that include among other things Safari hunting may experience bottlenecks during severe periods of environmental perturbations. Given the real threats of climate change some local communities have reported geobotanical, zoological, marine, and geomorphologic and livelihood changes [41]. From a study by St Lawrence University (2012) hunters faced random and severe climatic changes a situation akin to ecosystem change adaptation in semi-arid conditions in Southern Africa.

Widespread crop failure and livestock decimation are major issues during extended dry weather periods of up to two years [22]. The incidence of uncontrolled wildfires ravages commercial planted forests, home gardens and depletes household incomes and food security. The impacts of climate change may diminish wildlife populations across ecosystems [39]. Populations of hippopotamus, buffalo, eland, elephant, kudu, nyala, waterbuck, wildebeest and zebra, all experienced population declines during severe droughts. Resilience in ecosystem dynamics in semi-arid regions may be determined up to a point enabled by precipitation and prevailing management systems [42] (Figure 15).

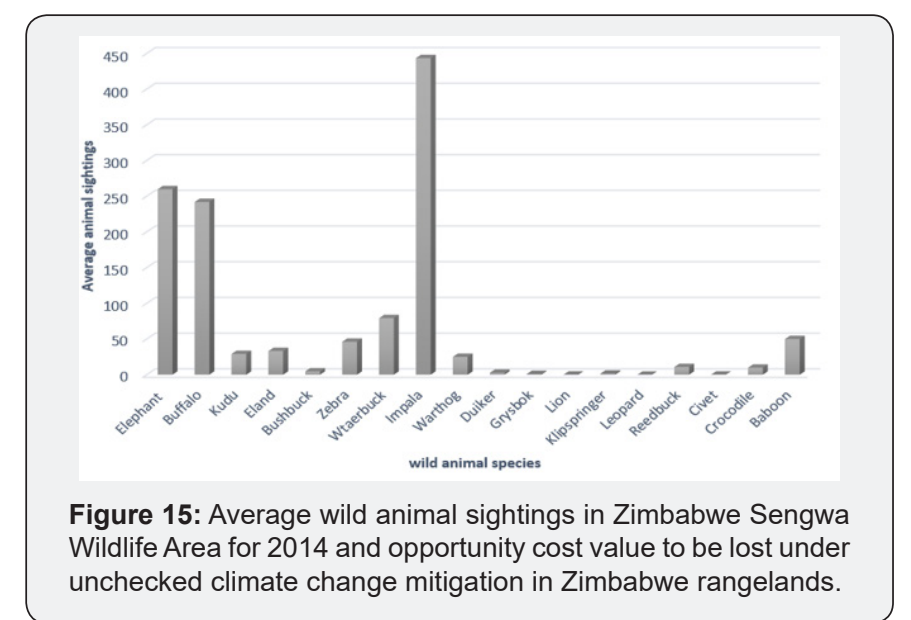

Development of an efficient game water policy for each of the game reserves with a wide spectrum of wildlife species is dependent on quality of climate data [43]. Determining shapes, sizes and orientation of water drinking pans and troughs to reduce water loss is a matter of conjectures of evaporation, precipitation and metabolic requirements of ungulate species and climatic factors. In the foregoing many livelihood aspects and maintenance of ecosystem functioning are cued on environmental condition and enabling adaptation climate policies [44-46].

\section{Conclusion}

Catastrophic climate mainly caused by severe episodic weather is one of the many constraints affecting semi-arid regions 
mostly due to lack of capacity to track changes in weather. Improvements in meteorological data should be augmented with IKS and databases. Atmospheric circulation data has to be recorded from a gamut of systems on ocean going vessels, drift meteorological instruments, balloon launches to upper air altitudes, satellites, radar and land-based weather monitoring systems. Automatic weather station transmitting weather data stand to guide smart watershed planning and improve prognostic and synoptic charts capabilities. In the progress of the review organised meteorological data is a recent effort of determining environmental condition but the outlook from the datasets is still blurred in terms of trends, patterns and scenarios in the visualization of data, long-term data should clear the fog for holistic planning. The review contends that environmental protection and safety can be improved if return intervals of severe episodic events are established to enhance preparedness in future catastrophic weather.

\section{References}

1. Ritchie H, Roser M (2018) Natural catastrophes- Our World in Data, USA.

2. Gibbens S (2018) Tropical Cyclone Michael. National Geographic Society 2015-2018 National Geographic Partners.

3. Scoones I (1996) Hazards and opportunities: Farming livelihoods in dryland Africa and lessons for Zimbabwe. In: Zed Books Ltd, UK.

4. Chenje M (2014) State of the environment in the Zambezi Basin 2000, p. 334.

5. Tyson P R (1986) Climate and Variability in Southern Africa. In: Oxford University Press, UK.

6. Dube L T, Jury M R (2012) Meteorological structure of the 1992/93 drought over eastern South Africa from ECMWF and Satellite OLR Analyses 170-181.

7. Chikoore H, Vermeulen J, Jury M (2015) Tropical cyclones in the Mozambique Channel: January-March 2012. Natural Hazards 77(3): 2081-2095

8. England M H, McGregor S, Spence P, Meehl G A, Timmermann Al, et al. (2014) Recent intensification of wind-driven circulation in the Pacific and the ongoing warming hiatus. Nature Climate Change 4(3): 222227

9. Drye W (2018) What forecasters got right and wrong about Florence. National Geographic.

10. Rapelewski DF and MS Halpert (1987) Global and Regional Scale Patterns Associated with El NiNo Southern Oscillation. Monthly Weather Review No 115.

11. Shen G and Hwang S (2015) A spatial risk analysis of tornado-induced human injuries and fatalities in the USA. Natural Hazards 77(2): 12231242.

12. IPCC (2007) Fourth Assessment Report, Synthesis Report, Geneva.

13. IPCC (2008) Fourth Assessment Report, Synthesis Report, Geneva.

14. IPCC (2009) Fourth Assessment Report, Synthesis Report, Geneva.

15. Winkler H (2010) Taking action on climate change: Long term mitigation scenarios for South Africa. In: UCT Press, Africa, p. 228

16. Mazvimavi D (2010) Hydrological changes over time of annual rainfall in Zimbabwe. Hydrological and earth system sciences 14: 2671-2679.
17. Jacobs C (2012) Southern Africa: region most affected by climate change.

18. Kandji S T, Verckor l, Mackenon J (2012) Climate change variability in southern Africa: impacts and adaptation strategies in agricultural sector. In: Icraf and unep, Kenya, p. 35

19. WHO (1998) Global Climate System Review. In: J M Nicholis (ed.) World Climate Data and Monitoring Programme, US, p. 856

20. Mashonganyika B (2016) An analysis of the Tokwe-Mukosi Disaster from a policy perspective. Bindura University of Science Education, US.

21. Agada S and Nirupano N (2015) A serious flooding event in Nigeria in 2012 with specific focus on Benue State: a brief review. Natural Hazards 77 (2): 1405-1414.

22. Unganayi I S (1994) A note from the Harare Regional Drought Monitoring Centre. Drought Network News, International Drought Information Centre. University of Nebraska, USA.

23. Lyons SW (1991) Origins of Convective variability over Equatorial Southern Africa during Austral Summer. Journal of Climate 4(1): 2339.

24. National Geographic (2018) National Geographic Society 2015-2018 National Geographic Partners, LLC.

25. Glantz M R Katz and N Nicholis (1991) Teleconnections: Linking Worldwide Climate Anomalies. In: Cambridge University Press, UK.

26. Meehl G A, Hu A, Arblaster Julie M, Fasullo J, Trenberth K E (2013) Externally Forced and Internally Generated Decadal Climate Variability Associated with the Interdecadal Pacific Oscillation. J Climate 26(18): 7298-7310.

27. Torrance J D (1972) Malawi, Rhodesia and Zambia. In: Griffiths J F (Ed). Climates of Africa. World Survey of Climatology, New York.

28. Daze Kitka G, Gyori K, Tatrai T, Oroszi V (2018) Interlinkages among global agendas: Applications of GIS for a climate disaster management in Csongrid Country, University of Salzbur, Austria.

29. Tafangenyasha C (1998) Phenology and mortality of common woody plants during and after a severe drought in South-eastern Zimbabwe. Transactions of the Zimbabwe Scientific Association 7: 1-6.

30. Tafangenyasha C, Marshall B and Naik Y (2016) Influence of agricultural runoff on the spatial distribution and abundance of benthic macroinvertebrates in the Runde River Zimbabwe. Zimbabwe Journal of Nutritional Ecology and Food Research 3: 1-11.

31. Owusu S, Wright G and Arthur S (2015) Public attitudes towards flooding and property-level flood protection measures. Natural Hazards 77(3): 1963-1978.

32. Codjoe Sand Afudio S (2015) Geophysical, socio-demographic characteristics and perception of flood vulnerability in Accra, Ghana. Natural Hazards 77(2): 787-804.

33. Guranyanga B J (1993) Drought Monitoring Centre- Activities, Outputs and Linkages into Early Warning Systems.

34. Zinyowera MC and L C S Unganayi (1983) Drought in Southern Afric: An update on the 1991-1992 Drought. In: International Drought Information Centre. University of Nebraska, USA.

35. Lem (2011) What we do and do not know. New scientist.

36. Ogalio LA (1994) Validity of the ENSO related impacts in Eastern and Southern Africa. In: In useable Food Science Security. UNEP, USA.

37. Matarira C H and Unganayi L S 1(995) A rainfall prediction model for southern Africa based on the Southern Southern Oscillation phenomena. Regional Early Warning Systems Project, Zimbabwe. 
38. Tafangenyasha C, Musungwa S, Kavhu B and Kuguyo T (2018) Solving the quandary of Environmental Education problems to improve sustainable environmental practice in Zimbabwe using concise principles of pedagogy and andragogy: a promise of living the future. Int J Env Science and Natural Resources 14(4).

39. EPA (2012) Environmental impacts of climate change. Department of Agriculture, Fish and Wildlife, USA

40. St Lawrence University (2012) Stories about adaptsation and subsistence of the Savoonga Siberian Yupik culture, USA.

41. UNEP (2012) Global Environment Outlook GEO-5. In: United Nations Environment Programme, Kenya, p. 572

42. Holt T, Altaf M, Mandli K, Hadwiger M, Dawson C (2015) Visualizing uncertainties in a storm surge ensemble data assimilation and forecasting system. Natural Hazards 77(1): 317-336.

his work is licensed under Creative

Commons Attribution 4.0 Licens

DOI: 10.19080/OFOAJ.2019.09.555767
43. Mason S J J A Lindesay and P D Tyson (199). Simulating drought in Southern Africa Using Surface Temperature Variations Water, South Africa.

44. Meteorological Department (2010) Climate change Research, Zimbabwe.

45. Ministry of Environment and Natural Resources Management (2013) Zimbabwe National Climate Change response strategy.

46. Ustrnul Z Wypych, A Henek, E Maciejewski M, Bochenek B (2015) Climatologically based warning system against meteorological hazards and weather extremes: the example for Poland. Natural Hazards 77(3): 1711-1729.

\section{Your next submission with Juniper Publishers} will reach you the below assets

- Quality Editorial service

- Swift Peer Review

- Reprints availability

- E-prints Service

- Manuscript Podcast for convenient understanding

- Global attainment for your research

- Manuscript accessibility in different formats

( Pdf, E-pub, Full Text, Audio)

- Unceasing customer service

Track the below URL for one-step submission https://juniperpublishers.com/online-submission.php 